\title{
Use of Audio-Visual Materials in Teaching and Learning of Classification of Living Things Among Secondary School Students in Sabon Gari LGA of Kaduna State
}

\author{
Adamu Tairu Idris', Ibrahim Muhammad Shamsuddin², Adamu Tairu Arome ${ }^{3,}$, , Ibrahim Aminu ${ }^{4}$ \\ ${ }^{1}$ Science Department, Funtaj International School, Abuja, Nigeria \\ ${ }^{2}$ Department of Chemistry, School of Science Education, Sa'adatu Rimi College of Education, Kumbotso, Nigeria \\ ${ }^{3}$ Biology Department, Federal College of Education, Zaria, Nigeria \\ ${ }^{4}$ Science Department, LGEA Anguwan Turaki, Soba, Nigeria
}

Email address:

marchity1@gmail.com (A. T. Arome)

${ }^{*}$ Corresponding author

\section{To cite this article:}

Adamu Tairu Idris, Ibrahim Muhammad Shamsuddin, Adamu Tairu Arome, Ibrahim Aminu. Use of Audio-Visual Materials in Teaching and Learning of Classification of Living Things Among Secondary School Students in Sabon Gari LGA of Kaduna State. Plant.

Vol. 6, No. 2, 2018, pp. 33-37. doi: 10.11648/j.plant.20180602.12

Received: June 12, 2018; Accepted: July 4, 2018; Published: August 15, 2018

\begin{abstract}
This research work examined the use of Audio-Visual Materials in teaching and learning among secondary school students in Sabon Gari Local Government Area of Kaduna State. Its main objective is to examine the impact of the use of Audio-Visual materials on the academic achievement of students. In this study, a quasi-experimental research design was used with a Classification of Living Things Achievement Test (CLTAT) as data collection instrument. This research analyze the necessity of audio-visual technology to teaching and also brings out the problems faced by using these technologies. It also aims to make science teachers aware of the strategies to use it in an effective manner. 100 students were used from five selected schools in Sabon Gari Local Government Area of Kaduna State for the study. The analytical tool used was t-test using the Statistical Package for Social Sciences version 22 (SPSS, 22). Thus from the results obtained, it shows that there is unavailability of such materials in the study area and with a significant level of 0.001 using T-test, it shows that using audiovisual aids in teaching classification of living things plays the role of enhancing students' academic performance.
\end{abstract}

Keywords: Audio, Visual, Audio-Visual, Teaching, Learning, Academic Performance

\section{Introduction}

Audio-visual is now permeating the educational system as a tool for effective teaching and learning. With audio-visual, the communication of information can be done in a more effective manner and it can be an effective instructional medium for delivering information. Audio-visual access to knowledge is one of the possibilities of information and communication technology that has tremendous impact on learning. The instructional media have emerged in a variety of resources, and equipment, which can be used to supplement or complement the teachers' efforts in ensuring effective learning by students. It is recognized that conventional media technologies can no longer meet the needs of our teaching and learning processes; as a result they are being replaced by audio-visual technology. This technology provides a learning environment that is selfpaced, learner-controlled and individualized.

Audio-visual is defined as the combination of various digital media types such as text, images, sound and video, into an integrated multi-sensory interactive application or presentation to convey a message or information to an audience. In other words, audio-visual means "an individual or a small group using a computer to interact with information that is represented in several media, by repeatedly selecting what to see and hear next" [1].

The power of audio-visual lies in the fact that it is multisensory, stimulating the many senses of the audience. It is also interactive, enabling the end users of the application to 
control the content and flow of information. This has introduced important changes in the educational system and impact the way teachers communicate information to the learners [2]. Ogunbote and Adesoye [3] expressed that audio visual technology adds new dimension to learning experiences because concepts were easier to present and comprehend when the words are complemented with images and animations. Stating further that it has been established that learners retain more when a variety of senses are engaged in impacting knowledge; and the intensity of the experience aids retention and recall by engaging social, emotional and intellectual senses.

The evolution of audio-visual aids has made it very possible for learners to become more involved in learning activity. With audio-visual technologies, learners can create audio-visual applications as part of learning project requirements. This would make the learners active participant in the learning process, instead of just being passive learners of the educational content.

Audio-visual involves processing, storage, generation, manipulation and retention of audio visual system, and the resources could include text files, pictures, video, audio, databases, archives, library catalogs, course notes, relevant links to various websites and easy access to search engines available on the Internet [4]. A study by Ubogu [5] supports the view that audio-visual resources facilitate access to all human knowledge, anytime, and anywhere in a friendly, multi-modal, efficient and effective way, by overcoming barriers of distance, language and culture, and by using multiple Internet-connect devices. It is important to say that the use of audio-visual technology has great significance in colleges, universities and research institutions in the Western countries. In these countries, the technology is being seen as a key player to development in all ramifications and essential component of education. However, Babajide \& Bolaji [6] identified different types of audio visual communication, some of which include computer science hardware, computer science software, public address systems, slides, overhead projectors, opaque projectors, videos, cassettes, audio tapes, cassette recorders, flip, time sequence, stream charts, Diorama still motion pictures among others.

Audio-visual in Education has been extremely effective in teaching individuals a wide range of subjects. Audio-visual is changing the way we communicate with each other. The way people send and receive messages is more effectively done and better comprehended. While a lecture can be extremely informative, a lecture that integrates pictures or video images can help an individual learn and retain information much more effectively. Using interactive CD-ROMs can be extremely effective in teaching students a wide variety of disciplines, most notably languages and music. A multisensory experience can be created for the audience, which in turn, elicits positive attitudes towards its application [2]. Audio-visual has also been shown to elicit the highest rate of information retention and result in shorter learning time [7].

However, information technology application serves different purposes, such as knowledge sharing-portal, search engines, public administration, social service and business solution. Omagbemi, Akinola \& Olayiwola [8] supporting this view expressed that access to audio visual information could stimulate changes and creates conductive learning environment and make learning more meaningful and responsive to the localized and specific needs of learners. However, Hoffman [9] suggested that successful implementation of ICTs need to address five interlocking frameworks for change namely the infrastructure, attitude, staff development, support (technical and administrative) and also sustainability and transferability. The many kind of ICTs implemented at teaching and learning can be used in education for different purpose. For instance, some audiovisual aids help students' with learning by improving the communication between the students and the instructors [10]. Studies have shown that, there are some factors that determine academics' use and non-use of new technologies for teaching and learning in the advanced countries and these include, the needs of the learner, the characteristics and experiences of academics, the technology available, the environment within which academics work and how valuable they perceive the use of technology to be for teaching their students $[11,12]$ and the disciplinary context of which the academic is part [13]. However, research have demonstrated that there are disciplinary and subject differences in the way ICTs are being used and adopted in teaching and learning $[14,15]$.

There is an urgent need to improve the quality of education to bridge the gap between developed and developing nations, and audio-visual instruction is considered as a necessary tool for this purpose. However, the presence of audio-visual alone will not stimulate significant changes in a school. Teachers are important ingredient in the implementation of audiovisual instruction in education. Without the involvement of teachers, most students may not take advantage of all the available potential benefits of audio-visual on their own. Teachers need to actively participate in the use of audiovisual facilities. Teachers have to be trained in the use of audio-visual and in its integration in the classroom activities to enhance thinking and creativity among students. Teachers must also learn to facilitate and encourage students by making them responsible for learning. Many of the current graduates were found to be lacking in creativity, communications skills, analytical and critical thinking and problem - solving skills $[16,17]$. In this study, attempts are therefore made at examining such issues as are pertinent to audio-visual utilization for teaching in the secondary schools of Sabon Gari Local Government Area of Kaduna State.

\section{Methodology}

The research design adopted for this study is quasiexperimental design, focusing on the use of audio-visual materials in teaching and learning computer science among secondary school students. The study employed the use of simple random sampling techniques. The study selected a sample size of one hundred (100) at random, with 
considerations to a similar characteristics shared by the main population. A purposive sampling will be adopted. The instrument for data collection for this study is Classification of Living Things Achievement Test (CLTAT). The validity and reliability of the instrument was determined by experts opinion and vetting comprising of researcher experts attesting to its relevance and appropriateness in the testing of the study. The students were taught the concept using traditional lecture method and were pre-tested, then exposed to same concept using audio-visual aids and were post-tested. The researchers used the t-test to analyze using Statistical Package for Social Sciences (SPSS) version 22 as a statistical tool for the data analysis.

\section{Results and Discussion}

\subsection{Status of Computer Models and Computer Software Resources}

It is required that the researcher to identify the types and quantities of computers and computer soft wares available in school for student's use during the normal teaching and learning process particularly as regards other subjects apart from computer studies. Information obtained from the observation schedules is that majority of the schools lack those software's which can be used to represent audio, visual or audio visual aids.

\subsection{Computer Laboratory}

Results obtained from analyzed data from observation schedules shows that three 3 of all the five (5) schools had a computer laboratory.

Table 1. Computer Laboratory Equipment.

\begin{tabular}{lll}
\hline Computer Equipment & Responses & \\
\hline & Frequency & Percentage \\
\hline Adequately equipped & 1 & 20 \\
Not adequately equipped & 4 & 80 \\
Total & 5 & 100 \\
\hline
\end{tabular}

Table 1 shows that of the 5 schools, 1 (20\%) was adequately equipped with computers, while $4(80 \%)$ were inadequately equipped indicating lack of equipment in schools.

Table 2. Computer Models Available.

\begin{tabular}{ll}
\hline Computer models & Frequency \\
\hline HP & 107 \\
COMPAQ & 36 \\
DELL & 10 \\
MECCER & 2 \\
ACER & 4 \\
Total & 159 \\
\hline
\end{tabular}

Table 2 shows that the most common models of computers in the sampled schools were HP with 3 out of the 5 sampled schools stocking a total of 107 computers of the brand, Compaq brand were found in totaling to 36 computers, Dell in totaling to 10 computers, Meccer in 12 and Acer totaling to 4 computers.

Table 3. Computer Projector.

\begin{tabular}{lll}
\hline Computer Projector & Responses & \\
\hline & Frequency & Percentage \\
\hline Available & 1 & 20 \\
Not Available & 4 & 80 \\
Total & $\mathbf{5}$ & $\mathbf{1 0 0}$ \\
\hline
\end{tabular}

Table 3 shows that only one (1) of the sampled schools 1 $(20 \%)$ had a projector while $4(8 \%)$ did not have a projector.

\subsection{Computer Printers}

All the 5 schools had a printer each located either in the computer laboratory or some offices. The general picture was therefore of schools having computer laboratories equipped to handle minimal number of students unlike the large populations of students taking computer science - a compulsory subject in every school. Since most of the schools were found to have large population of students per stream in each class with each class having more than one stream, it is highly probable that the computer hard wares and soft wares were inadequate for their use.

\subsection{Test of Hypothesis}

$\mathrm{HO}_{1}$ : The application of audiovisuals does not have a significant positive impact in teaching Classification of Living Things

Table 4. T- Test Analysis of Achievement in Classification of Living Things when exposed to the use of Audio-Visual Aids.

\begin{tabular}{llllllll}
\hline Variable & N & X & S. D & S. E & Df & t-value & P \\
\hline Post-Test & 100 & 53.60 & 9.184 & 1.040 & 99 & 51.547 & 0.001 \\
Pre-Test & 100 & 44.66 & 4.364 & 0.617 & 99 & Remarks & 72.362 \\
\hline
\end{tabular}

Significant @ P $\leq 0.05$

The hypothesis says that; the application of audiovisuals does not have a significant positive impact in teaching Classification of Living Things among secondary schools students in Sabon Gari LGA, Kaduna state. From the t-test result above, it is clearly evident that the use of audio-visual aids play a significant role in teaching of Classification of Living Things and hence the null hypothesis which says that; the application of audiovisuals does not have a significant positive impact in teaching Classification of Living Things is hereby rejected and alternative hypothesis which say; The application of audiovisuals have a significant positive impact in teaching Classification of Living Things is hereby retained. This finding seems to be in agreement with that of Norton [18] who in studying Brisbane teachers' responses to and beliefs about using computers for mathematics learning found that: (i) few secondary mathematics teachers used 
computers at least weekly; (ii) computers were considered equally or more effective than traditional instruction for doing calculations or providing basic skills practice; few teachers considered computers useful in developing conceptual understandings. The effective use of technology depends on the teacher. Teachers should use technology to enhance their students' learning opportunities by selecting or creating mathematical tasks that take advantage of what technology can do efficiently and well - graphing, visualizing, and computing [19]. Bringing computers into classrooms can have profound effects on teachers. In the U.S., Simpson, et al. [20], found in their study that only half of the public school teachers who had computers available in their schools used them for classroom teaching and learning. The teachers' perceptions of the barriers to computer and Internet use for instruction were also examined. Most frequently, the teachers reported lack of release time to learn how to use computers or the Internet $(82 \%)$, lack of time in the daily schedule for students to use computers in class $(80 \%)$, and insufficient numbers of computers $(78 \%)$ as the major barriers, findings quite eminent in this study. Similarly Hadley and Sheingold [21] had reported a similar, related set of barriers to computer use that teachers identified in this study. These included: lack of appropriate software or information about it; teachers' self-doubt, lack of interest or knowledge about computers; inadequate numbers of computers; and lack of maintenance, support, advice, and upkeep. In a fairly recent large Australian study, Finger et al [22] found that most of the participating teachers had very high levels of basic computer skills, with a much lower proportion reporting advanced skills.

\subsection{Summary of Findings}

i. There is lack of audio-visual materials in the selected schools

ii. The use of audio-visual materials in the sampled schools is poor

iii. Audio-visual aids are adequate in teaching and learning as they boost students' performance

\section{Conclusion}

Based on the results obtained in this study, the following conclusion were made; Integration of Audio-Visual Aids in the teaching and learning of classification of living things in the study area suffer from inadequate computer infrastructure in schools, ill equipped and overburdened teaching force and overstretched school budgets incapable of sorting out the financial challenges that the schools face relative to computer integration in the teaching and learning process. There is need to address those factors affecting Audio-Visual Aids use in teaching and learning of science in order to integrate its use in the teaching and learning in schools. Use of AudioVisual Aids enhanced and facilitated the acquisition of knowledge and skills more than the use of traditional teaching method.

\section{Recommendations}

Based on the findings of this study the following recommendations are put forward by the researcher:

a. Education stakeholders in the country should finance provision of computers, power generator, Audio-Visual Aids, and expand computer laboratories in all secondary schools. This will enhance the use of computers in the teaching and learning.

b. All teachers should be trained on using Audio-Visual Aids to teach due to lack of computer skills.

c. The PTA, educational stakeholders and the government through MOE who finance free secondary education should increase its allocation on tuition fees and encourage schools to have a specific vote head for computers so as to ensure reliable funding of computers by schools. However MOE should ensure use of the funds efficiently and effectively to create sustainable computer programs in their schools.

d. Ministry of Education and professional organizations like STAN should organize workshops, seminars and conferences for lecturers and teachers especially on how to manage Audio-Visual Aids.

\section{References}

[1] Agnew, P. W., Kellerman, A. S. \& Meyer, J. (1996). Multimedia in the Classroom. Boston: Allyn and Bacon.

[2] Neo, M. and Neo, T. K. (2000). Multimedia learning: using multimedia as a platform for instruction and learning in higher education. Paper presented at the Multimedia University International Symposium on Information and Communication Technologies 2000 (M2USIC'2000), October 5-6, 2000, Petaling Jaya, Malaysia.

[3] Ogunbote, K. O. and Adesoye, A. E. (2006). Quality assurance in Nigerian academic libraries networked multimedia services. Journal of Library and Information Science, Vol. 3. No. 1 \& 2 pp. 100-111.

[4] Shuell, T. J. and Farber, S. L. (2001). Students perception of technology use in college courses. Journal of Educational Computing Research, Vol. 24 P. 125.

[5] Ubogu, F. N. (2006). Trends in digital library services in academic libraries in South Africa: library profiles and ETD system. Conference proceeding of the 44th Annual National Conference and AGM of Nigerian Library Association held at Abuja, Nigeria, pp. 18-23.

[6] Babajide, J. F. T. and Bolaji, O. A. (2003). Perception of lecturers and pre-service teachers towards the use of communication media in teaching pure and applied sciences in related disciplines. Proceedings of Conference, Lagos: pp. 23 -40 .

[7] Ng, K. H. and Komiya, R. (2000). Introduction of Intelligent Interface to Virtual Learning Environment. Paper presented at the Multimedia University International Symposium on Information and Communication Technologies 2000 (M2USIC'2000), October 5-6, Petaling Jaya, Malaysia. 
[8] Omagbemi, C. O., Akinola, B. A. and Olayiwola I. B. (2004). Academic libraries, the Internet and it's potential impact on teaching and learning in Nigerian tertiary institutions. Journal of Library and Information Science, Vol. 1 (1 \& 2), pp. 34-46.

[9] Hoffman. B. (2001). What drives successful technology planning? Journal of Information Technology for Instructor Education, 5 (1/2), 46.

[10] Valasidou, A., Sidiropoulos, D., Hatzis, T. and BousiouMakridou, D. (2005). Guidelines for the design and implementation of e-learning programmes. Proceedings of the IADIS International Conference IADIS E-Society, 27 th 30th June, Qawra, Malta.

[11] Chun, L. W. and Kwan, W. T. (2005). Towards developing a profile of ICT use among IPBA lecturers. Jurnal IPBA, Jilid 3: Bil 3. Available online at

http://apps.emoe.gov.my/ipba/rdipba/cd1/article92.pdf. Accessed on 7th March, 2009.

[12] Munoz - Repiso, A. G. and Tejedor Tejedor, F. J. (2006). Use of information and communication technology in higher education and lecturers' competencies. Current Development in Technology -Assisted Education P. 1788.

[13] Rowley, J., Banwell, L., Childs, S., Gannon - Leary, P., Lonsdale, R., Urguhart, C. and Armstrong, C. (2001). User behaviour in relation to electronic Information services within the UK higher education academic community. Journal of Educational Media, Vol. 27 No. 3, 114.

[14] Zones, C., Zenios, M. and Griffiths, J. (2004). Academics use of digital resources: disciplinary differences and the issue of progression. Networked Learning: Proceedings of the Fourth International Conference, Sheffield University.

[15] Eynon, R. (2006). The use of ICTs for teaching and learning in Law Education: some innovators' perspectives. Web Journal of Current Legal Issues, (Web JCLI), Issue 3. Available online at http://webjcli.ncl.ac.uk/2006/issue3/enyon3.html. Accessed on 22nd January, 2009.
[16] Teo, R. and Wong, A. (2000). Does Problem-based Learning create a better student: a reflection? Paper Presented at 2nd Asia Pacific Conference on Problem-based Learning: Education Across Disciplines, December 4 - 7, Singapore.

[17] Tan, O. S. (2000). Thinking skills, creativity and problem based learning. Paper Presented at the 2nd Asia Pacific Conference on Problem-based Learning: Education Across Disciplines, December 4-7, Singapore.

[18] Norton, S. (1999). Secondary mathematics teachers' responses to computers and their beliefs about the role of computers in their teaching. In J. M. Truran \& K. M. Truran (Eds.), Making the difference. Proceedings of the Twenty-second Annual Conference of the Mathematics Education Research Group of Australasia [MERGA] (pp. 404-410). Adelaide, Australia: Mathematics Education Research Group of Australasia Inc.

[19] NCTM (2000). Underpinning the Principles and Standards for School Mathematics. National Council of Teachers of Mathematics. Reston.

[20] Simpson, M., Payne, F., Munro, R. and Hughes, S. (1999). Using information and communications technology as a pedagogical tool-who educates the educator? A paper presented at the European Conference on Educational Research, Lahti, Finland, 22 - 25 September.

[21] Hadley, M., \& Sheingold, K. (1993). Commonalities and distinctive patterns in teachers' integration of computers. American Journal of Education, 101, 261-315.

[22] Finger, G., Russell, R., \& Russell, G. (1999). "Information technology and Australian teachers: Real time: Computers, change and schooling--National sample study of the information technology skills of Australian school students." Paper presented at the Australian Association for Research in Education and the New Zealand Association for Research in Education joint meeting. Retrieved November 4, 2011, from http://www.aare.edu.au/99pap/fin99548.html. 